\title{
Analysis Research for Strategic Development Policy of "A Competitive Albania, with a High Dynamic Enterprise and Productive Industry"
}

\author{
PhD candidate Elmira Kushta ${ }^{1}$
}

\author{
Prof. Dr. Alba Dumi² \\ PhD Evis Çelo ${ }^{3}$
}

\author{
1 Department of Mathematic" University of Vlore, Albania; Email: kushtamira@gmail.com \\ 2Dean of Graduated School "Ismail Qemali" University of Vlore; Email: alba.besi12 @gmail.com \\ 3Language and Management Department" University of Vlore, Albania; Email: evis.celo8@gmail.com
}

\section{Doi:10.5901/mjss.2015.v6n4p219}

\section{Abstract}

Albania is reforming its society and political mentality to better-fit new needs and responsibilities toward the European Union and western values the country always dreamed. Nevertheless, the political mentality of the past, which today is part of the process of political reformation, is slowing the process of integration toward western values. Political forces somehow are resisting the upgrade of their political mentality to these newer western political concepts. Albania had made big steps reforming the economy, and the political class is committed in making the country desirable for foreign investors as well as creating comforts for domestic ones. A successful integration is occurring, although several challenges need to be considered in order to fasten this process.

Keywords: Albanian development economy, Variables, Math studies, Administration role, Management policy, EU standards, Public sector, Democratic state,

\section{Introduction}

"A competitive Albania, with a high dynamic enterprise and productive industry" This strategy is viable to national and regional level. It will affect the economic development of regions, based on the competitive advantages that these regions can provide where her vision will be materialized in:

A Competitive Albania: It is towards a more competitive economy and dynamic one, more foreign investment, in order to enhance the diversification of exports and to deliver new business creation. The need to continually improve the competitive position of Albania towards its regional neighbors, partners, European and global level is national ambitions. Attention will be focused towards Albania's natural competitive advantages, improving the productivity of human resources and natural resources, mobilizing untapped potentials of Albania in terms of natural resources, agricultural and tourism development, strategic geographical position for trade and transport and energy development as a prerequisite for the growth of industrial production. Creating a partnership between government and business matched with the need to improve technology, innovation and ability to prepare "skilled employees".

A Country that stimulates the development of entrepreneurship and SME:

Continuous improvement of business and investment, as a reducing administrative barriers and business costs as the basis to secure the development of productive capacities

By 2020, Albania will improve the legislative and institutional framework for SME focusing on the liberation of entrepreneurial potential of its small businesses and medium. Albania aspires to be the leader in the region with respect to key parameters on the global business-friendly environment and benchmark-tions such as the World Bank report 'Doing Business' and the Small Business Act to the EU.

- Development of a productive industrial sector and mining, able to process raw material and money within the country and increase their value through investment promotion and application of new technologies, cleaner production, professionalism and employment growth, which stimulates the creation of the base of a competitive industry.

By 2020, Albania will realize its full potential through a combination of potential industrial rich mining and energy 
production potential. It aims towards an integrated production of industrial goods ready for export to world markets. It is intended to be used on a large mineral wealth increasing by supporting investors in the mining sector with fast and efficient management of all matters relating to licenses and permits to grow the chain of industrial value added internally by using energy sources. It is in the interest of the country to build a strong industrial foundation in Albania and with the aim to coordinate with existing industrial capacity to its neighbors like Montenegro, Kosovo and Macedonia, in order to become part of industrial helpful in region with integrated guide .

-An open Albania towards regional markets, European and global one

Within 2020 Albania intends to be fully integrated into regional markets, European and global one. Within 2020, Albania will be an important part of the European internal market with all the benefits and its competitive forces. It will be reassessed competitive advantages, its export potential and opportunities for new markets for products

\section{The competitiveness of Economy}

As far as Albania aspires to become a candidate for membership in the EU, the EU benchmark is important, but also important is the comparison with the countries of South Eastern Europe (SEE) in terms of competitiveness. So GDP per capita in 2011, according to Eurostat, in Albania was at 30\% of GDP per capita in PPS compared to the average EU-27, $11 \%$ compared to GDP / per capita is the highest that has Luxemburg and 66\% of GDP / per capita compared to the country with the lowest level in the EU is Bulgaria.

According to the Global Competitiveness Report of the World Economic Forum 2012-2013, Albania is ranked 89-th out of 144 countries / economies. Albania is classified in the group of countries that are in the second stage of development of competitiveness (also is called a "catalytic stage of economic efficiency") .When economies are transferred to the stage of efficiency, not any longer their competitiveness is based on low prices, but in quality of goods and services.

Considering three main dimensions (basic requirements, increased efficiency, innovation and sophisticated factors) index, Albania has the highest score in the first indicator " " basic requirements "(4.2 points), ranked in position 87-th. Looking column within these dimensions, the best rankings of these column, are "health and primary education" (5.6 points), "labor market efficiency (4.4 points)," goods market efficiency '(4.3 points); macroeconomic environment (4.3 points).
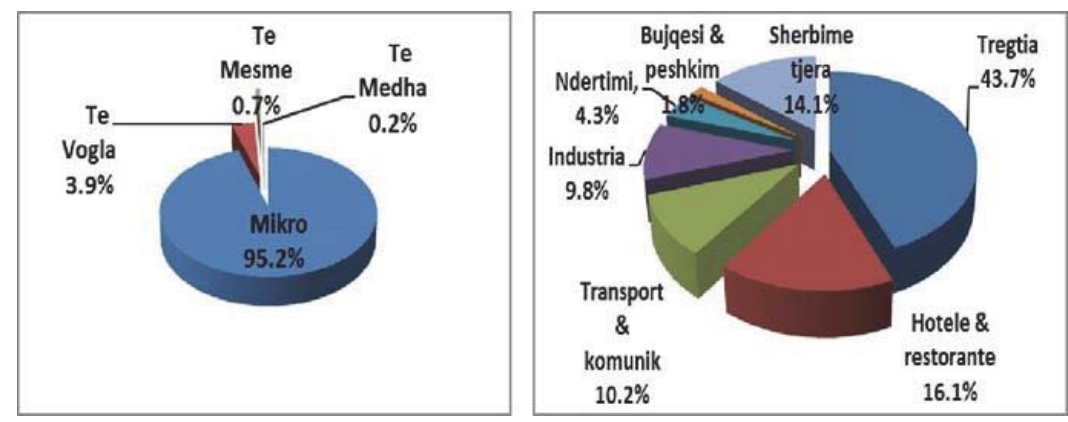

Graph 1: Indicators of Albanian Development Progress in Economy ,Source AJISS study 2014

\section{Results of the Survey}

In terms under indicators, Albania ranks well enough "legal rights index" in 9th place, "time to start business" in 9th place, "investor protection" in place of 15- to, "pay and productivity" in 17th place, "administrative regulatory burdens for business" in 9th place. Most problematic factors for doing business according to the report are: access to finance, tax rates, corruption, and tax regulation.

In regional rankings, first place in the Top ranking was Montenegro. Albania is almost on the same level on ratings with Bosnia-Herzegovina and Serbia leaves after 6 countries. After years of steady progress, Albania only in the last 2 year period from 2012 to 2013 has shown a decline in the ranking, which can be in a certain extent the impact of external factors (economic crisis).

While increasing competitiveness of the economy in recent years is due in large measure to government reforms, but as the country turns to be the most competitive is required an emphasis on factors of innovation, technological 
preparedness, ahead improvement of infrastructure and consolidation of institutions.

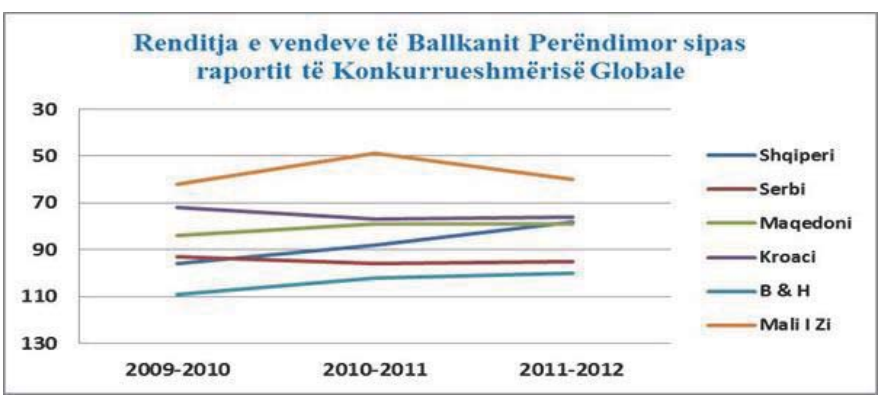

\section{Graph 2:}

Source: Doing Business database, 2012-2013

According to the "Index of Economic Freedom 2012" report to the Heritage Foundation and the Wall Street Journal, which covers 10 liberties - from property rights to entrepreneurship - among 184 countries of the world, Albania score (65.1 points) being ranked $57^{\text {th }}$ in the world and in the $26^{\text {-th }}$ place among 43 European countries.

Albania is classified in the category of countries with moderate economic freedom (liberties) above the global average (59.5) and grew to a point in the ranking compared to last year, mainly for improvement in the fight against corruption and business freedom.

The dimensions with the highest ranking of economic freedom remain "fiscal freedom (liberties)" (91.4 points), followed by " monetary freedom (liberties)" (78.6 points or 11.1 points more than in 2011)," commercial freedom "(79.8 points). Dimensions with lower ranking are 'freedom from corruption' (33 points) with an improvement of 1 point from 2011 and "property rights (35 points) with no change from last year.

The report notes that economic dynamism is increased, and the country has experienced a strong economic growth, which has reduced poverty and unemployment rates. Efficiency regulatory system is facilitated by a large-scale simplification of business procedures. The establishments of Albanian economic freedom are unstable by weak protection of rights property and widespread corruption.

The weak protection of property rights is primarily the result of political interference in the judicial system. World Bank: Ease of doing business from 2012 to 2013.

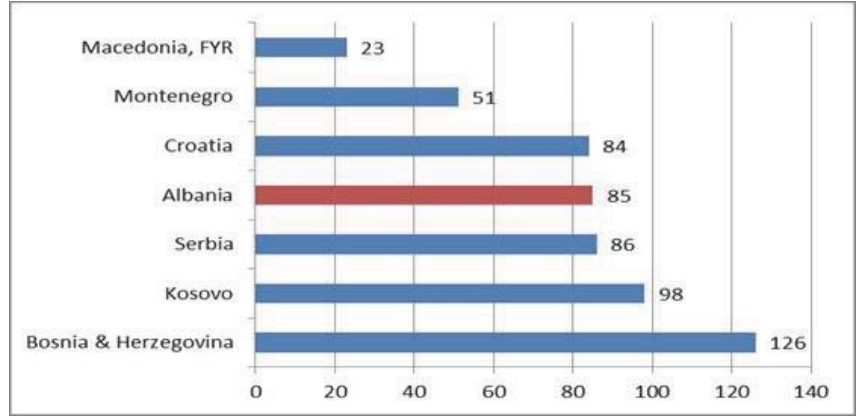

\section{Graph 3}

\subsection{Business development and challenges}

According to the World Bank report "Doing Business 2012-2013", Albania is ranked 85-th out of 185 economies, a ranking better than other countries of the Western Balkans, such as Bosnia \& Herzegovina and Serbia. The figures show that the ranking of Albania has been almost unchanged in the last three years, but significant qualitative and recorded from 2007 to 2009, the year in which there was an improvement in the order of about 51 places higher, from the position of 136 at 85.

However, in the ten criteria there is a great diversification of achievement, marking positively in terms of protecting 
investors, receiving the loan, starting a business and emphasizing the need for further substantial improvements in: permissions of constructions, connection with energy and registering property. Albania is still classified at low levels: i) further reduction of the procedures for starting a business, ii) reducing the time for issuing the construction permission; iii) the number of $d$ the supply of electricity; iv) the number of days and procedures for registering property; $v$ ) reduction of documents in customs; vi) in respect of contracts; vii) bankruptcy, etc.

\subsubsection{Improvement of these indicators is one of the challenges of this strategy.}

During recent years the Albanian government has undertaken significant reforms for utilizing the Albanian economy in the formal sector. Entry into force of the flat tax, the establishment of fiscal cases, reform of the VAT system, improvements of procedures to the tax authorities, the success of the National Registration Center and simplifying business licensing procedures have been very successful reform of Albania, which has shown that economic growth despite the global crisis. Albania, too, in the last 5 years has become overrun in most global rankings on reforms and competitiveness. However, a significant part of the economy remains in the informal sector.

Albanian Government with the support of the donor community has been the leader in the region in terms of efforts on electronic governance and pervasive system of procurement on line in operation in Albania is a success story for which Albania has been hailed in the international arena. Great efforts are being made in the field of taxation, implementation and transparency with database online properties and similar efforts are being made in health and education.

As a result of major developments and reforms in the last decade some of the industries began to adapt to the new conditions: metallurgical industry as part of the minerals industry using existing premises used for the processing of chrome, concentrates chrome and ferro (iron)-chrome; the industry of copper processing is also used as raw material respects, experience and cheap labor costs, coming out on exporting copper concentrate product.

\section{Methodology of the Paper Research}

Investments during the last 20 years have been directed mainly towards the construction minerals, (on the demand for building materials and products, infrastructure and cement). The fact that investment in metal minerals is a growing trend in recent years is related to the growing trends for these minerals in regional and global markets, especially for processed products.

Strengthening of several small and medium companies in this sector has created the capacity to enter in the international market for mining.

The reduction of rich mineral reserves, beginning of exploitation in depth, necessarily requires further processing, thereby encouraging the construction of enrichment mineral factories, which is a tendency observed in the last three year period primarily chromium and copper.

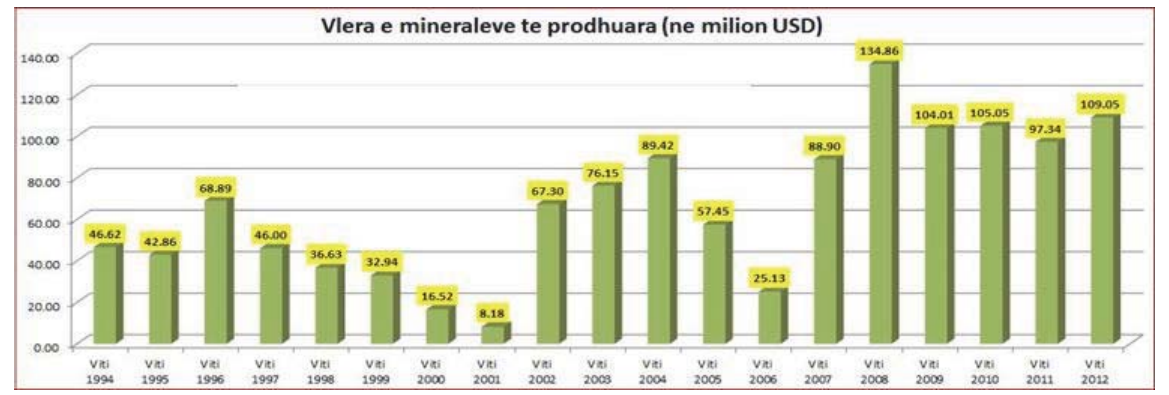

The value of mineral products in year: METE

Graph 4. The value of mineral products in years

Current favorable conjuncture of mineral prices has caused many investors to turn to the mining sector, particularly tometal minerals, chromium, copper, nickel, iron, nickel and TITANO-magnet.

Energy needs are noting once again the possibility of reopening the mining of minerals energy by calculating the cost of energy produced by them in a situation where the unit price of energy has increased and closing or mining 
conservation of energetic minerals become in other situations, the first and new opportunity to our system balancing energy through small capacity thermal power plants, near the mining.

Challenges for the development of industry, stay in directing investments that affect the development of products and value-added sectors as high. It is intended to further deepening the liberalization process in the domestic (internal) market, to bring new energy to: i) industrial development, research and product development, new products for export, suitable conditions for the development of a culture of entrepreneurship, business networks, technological cooperation and innovation; ii) development of market institutions combined with the coordinating role of the state with the balance located in the functioning of the free market; iii) the orientation of the policies implemented in terms of increased foreign investment flows in infrastructure development in terms of technological capacity utilization, improving legislation,

iv) improving the efficiency of services provided by public administrations to support industrial development, research and development of new products in order to increase the value of the country's exports and business;

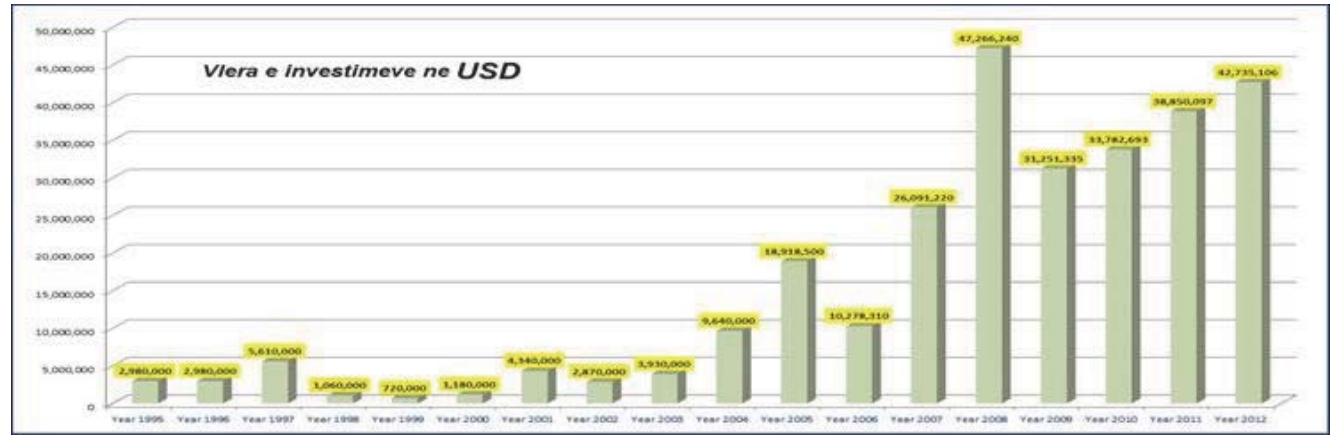

Graph 5. The value of investments in the mining sector 1993-2011

Source: METE

\section{Findings and Hypothesis}

The scale of opening of economy as the ratio of trade volume to GDP has been steadily increasing. In 2011 it was about $58 \%$ to $42 \%$ in 2006 . The year 2009 is the only year in which the ratio of exports and imports in GDP had a slight decrease. Since 2010, this ratio has increased significantly, reaching in 2011, about $15 \%$ for exports and $43 \%$ imports

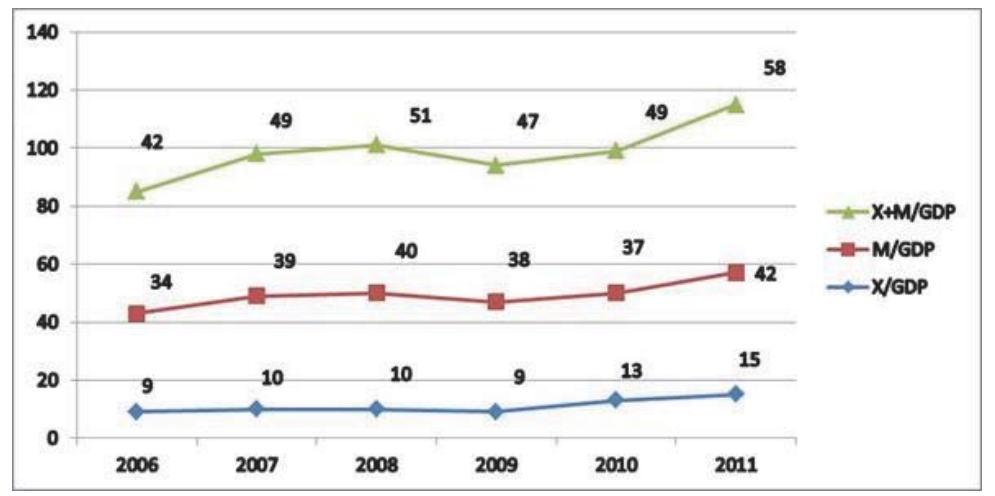

Graph 6. The degree of openness, as the ratio of trade volume to GDP

The percentage of coverage of exports to imports has increased in favor of exports in 5 last years. The percentage of coverage of exports to imports for 2011 is $36 \%$ or 1 to 3 which until 2008 was in figures 1 to 4 . The balance of trade in goods and services has improved its relation to GDP, from $-24 \%$ to $-22.7 \%$.

Exports by commodity groups : Potential sectors for export products remain the same as those already called traditional sectors:

1. Textiles and outfits foot remain a considerable potential for increasing export volumes. This sector comprises $32 \%$ of total exports. 
2. Minerals and hydrocarbons (oils) in Bangladesh are another potential for 2011 has reached $27 \%$ of total exports.

3. Materials of construction constitute about $13.5 \%$ of total exports.

\begin{tabular}{|l|c|c|c|c|c|c|}
\hline Exports by commodity groups & \multicolumn{6}{|c|}{ Exports in million Euro } \\
\hline & 2006 & 2007 & 2008 & 2009 & 2010 & 2011 \\
\hline Minerals and hydrocarbons & 47.2 & 121.3 & 166 & 156 & 324 & 418.15 \\
\hline Textiles and outfits foot & 344.6 & 380 & 397 & 367 & 403.6 & 455.6 \\
\hline Materials of construction & 108.28 & 125.8 & 185.65 & 100.15 & 237.75 & 299.4 \\
\hline
\end{tabular}

Source: METE

Exports of key items have a significant increase since 2006, i.e. 8.7 times minerals and hydrocarbons, 1.3 times textiles and footwear, 2.8 times of construction materials

\subsection{Exports by destination countries}

Exports to EU countries account for $72.5 \%$ of all exports with an increase of $26.5 \%$ compared with the end of 2010 . The country's main exports go to: Italy, Greece, Spain, Germany, Malta, etc. As it is seen in the chart below, one of the main partners of our exports by $53 \%$ is Italy, then Greece with $5.2 \%$, etc. After the implementation of CEFTA 2011 , Albanian exports to countries CEFTA members have followed a marked change occupying a specific weight of $12.4 \%$ overall versus export's constituting 10.2\% in 2010. Compared to 2010, 2011 exports to CEFTA countries have a growth by 47\%.

\section{Analyze and Research}

The aim is to create a digitezed map of the schools and universities for effective educational planning and policy development and appropriate educational decision. This process is accompanied by training of central and educational institutions in view of information management system of particular importance will be given with partners in the sector through:

-H1: The development of criteria for partnership with local and internacional companies to provide and deliver digital educational content for basic and seconadry education

If the school fails to meets its standards and students achievements goals,set in its own development plans, then the responsibilty rests with the teaching and school leaders. In such cases,local govenment,based on devolved responsibilities within educational sector Decentralization may limit the responsibilities delegated to schools and distribute the school board or the education board.

-H2:The development of a platforms as a part of a master plan for ICT investment that will enable he foreign companies in the fields of ICT for the benefit of education

Dual monitoring system stimulates the use of multliple method for reporting and auditing ,increased transparency of the process and the reliability of conclusion reached.The combination of internal monitoring and external anabling effective action for improvements in the form of assistance from specialized units of local and national.

$-H 3$ :The Albanian investment provided the development and implementation of the broader policy changes and allowed the Public Administration Reform project to focus in direct and positive impact of people themselves

Kosovo has traditionally been the main export country within CEFTA, with a specific weight of $60 \%$ of total exports to CEFTA. Albania's exports to Turkey in 2011, occupying 7.5\% of total exports and increased by $63 \%$ compared to a year ago. Many Eastern European countries have followed the drastic decline of FDI flows in 2010, while Albania has absorbed more than last year. After 717 million euros in 2009, FDI flows in 2010 came to 793 million euros. In 2010 Albania was ranked second highest amount of FDI in SEE after Serbia (Graph 11), according to the report on foreign investments AIR 2011. 


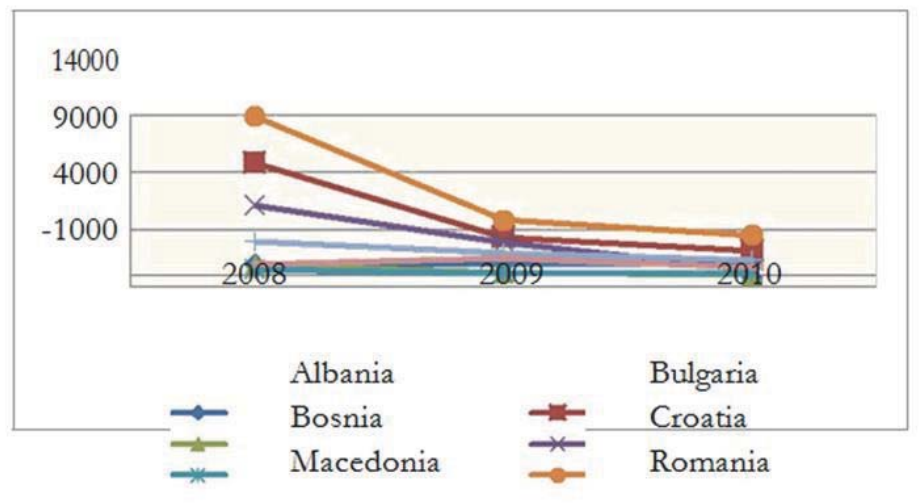

Graph. 7. The flux of FDI in Eastern Europe in 2008-2010 in Million USD Source: WIR 2011

\section{Conclusions}

In the last decade the government policies and regulatory framework for business are based on the principles of good governance with the primary focus transparency, pre-viewing and simplicity of practices implemented. The regime of Liberal tariff and the network of free trade agreements, expanded further by expanding the application of the principle of origin cumulate have enabled raising the Albanian exporters to enter in new markets. Business in Albania still faces many problems, the solution of which is indispensable as it has a direct impact on the Albanian economy.

Through increasing the competitiveness of domestic(internal)production, which consists not only in high value export, but more items for export diversification increasing technological content and level of qualification, thereby reducing the need to import, to export growth and penetration of "Made in Albania" in new markets, which are real challenges for exporting companies:

Business in Albania still faces many problems, the solution of which is indispensable as it has a direct impact on the Albanian economy.

\section{References}

Barjaba, K. (1998, June). Albania in transition: Elite's role and perspectives. Final Report of the research project, Tirana-Albania, 1998 nato.int. Retrieved from NATO Individual Academic Fellowship Program database. acad/fellow/96-98/barjaba.pdf

Dumi A, MCSER 2011Albania and Progress in all fields of economy

Dumi A New Zealand Conference 2014,The Role of Community-Based Organizations in Management Access and Success of Public Administration Development

Elbasani, A. (2004, June). Albania in transition: Manipulation or appropriation of international norms. Southeast European Politics. Vol. V. No.1, pp. 24-44. Retrieved from Southeast European Politics, 2004 - seep.ceu.hu archives/issue51/elbasani.pdf

Freedom House Reports. (2008, October). Nations in Transit 2008, Albania (Freedom House publication 23 June 2008). Bushati, D: Author. Retrieved from Freedom House website site at www.freedomhouse.hu/nitransit, Organization database/2008/Albania 2008.pdf.

Goldman F., M. (1997). Revolution and Change in Central and Eastern Europe; political, economical and social challenges. Illustrated edition. M. E. SHARPE.

Guçe, M. (2000, January). The problems encountered by Albanian democracy. What can and what should Albanians do?. Retrieved from SEER SouthEast Europe Review for Labour and Social Affairs, issue: 01 / 2000, pages: 119129, on www.ceeol.com.

Muço, M. (1997, June). Economic transition in Albania: Political constraints and mentality barrier. NATO Individual Fellowship Program 95-97, nato.int

U.S. Commission on Security and Cooperation in Europe. (2004, October). Helsinki Commission holds hearing on advancing democracy in Albania (CSCE publication Vol. 37 No.17). Hand, R: Author. Retrieved from Helsinki Commission's website site at http://www. csce.gov

U.S. Department of State. Background Note: Albania (2008, November). Bureau of European and Eurasian Affairs. Retrieved from Department of State's website site at http://www.state.gov/r/pa/ei/bgn/3235.htm

Vurmo, Gj., Sulstarova, E. (2007, June). Albanian perception on NATO integration. Institute For Democracy And Meditation, IDM IDM idmalbania.org. Retrieved from IDM database. publications/en/AlbPerceptionOnNATOintegrations.pdf 